\title{
PENGARUH LEVERAGE, UKURAN PERUSAHAAN DAN INFLASI TERHADAP PROFITABILITAS PADA BANK UMUM SYARIAH DI INDONESIA
}

\author{
Imam Syafi'i ${ }^{1}$, Slamet Haryono ${ }^{2}$ \\ 1,2 Universitas Islam Negeri Sunan Kalijaga, Yogyakarta \\ \imamrezp51@gmail.com¹, slamet.haryono@uin-suka.ac.id²
}

\begin{abstract}
The company has orientation to gain profit in carrying out business activities. There are factors that affect the company's profitability, both internally and externally. Company management, must control their financial ratios and consider macroeconomic and environmental conditions because these factors can affect the company's profitability. The purpose of this study is to examine the effect of leverage, firm size and inflation on the profitability of Islamic Commercial Banks in 2012-2019. This type of research is quantitative research. The object of this research is the banking sector companies, namely Islamic Commercial Banks registered with the Financial Services Authority (OJK) in the period 2012 to 2019. The sampling technique used is purposive sampling technique. The method used for data analysis is panel data regression, which is a combination of cross section data and time series data using data from 10 Islamic Commercial Banks. The findings of this study indicate that the leverage that uses the DER indicator partially has a significant positive effect on the profitability of Islamic banking, which uses the ROA indicator. Furthermore, the size of the company that uses the indicator Ln Assets and Inflation does not have a significant partial effect on profitability at Islamic Commercial Banks, but has a simultaneous effect. The variables of leverage, firm size, and inflation simultaneously affect the profitability of Islamic Commercial Banks.
\end{abstract}

Keywords

: Aset, Inflasi, Leverage, ROA.

\section{LATAR BELAKANG}

Perusahaan memiliki orientasi untuk mendapatkan keuntungan dalam menjalankan kegiatan usaha. Kinerja suatu perusahaan dapat mempengaruhi profitabilitas, namun terdapat beberapa faktor lain yang dapat mempengaruhi profitabilitas perusahaan, baik secara internal dan eksternal. Manajemen perusahaan, dapat mengontrol rasio keuangan mereka dan mempertimbangkan kondisi makroekonomi serta lingkungan, karena faktor-faktor tersebut dapat mempengaruhi profitabilitas suatu perusahaan (Puche, Miguelez, Soria, \& Gamez, 2020). Perkembangan keuangan perusahaan memiliki dampak positif terhadap profitabilitas bank, pertumbuhan ekonomi dan keuangan global juga dapat mempengaruhi profitabilitas bank (Le \& Ngo, 2020). Profitabilitas perusahaan juga dipengaruhi oleh umur perusahaan, biaya tenaga kerja, konsentrasi industri, dan Gross Domestic Product serta inflasi (Pervan, Pervan, \& Ćurak, 2019).

Yuksel dkk melakukan penelitian pada sektor Perbankan yang mengidentifikasi bahwa determinan profitabilitas bank di 13 Negara pasca-Soviet menemukan bahwa 
jumlah pinjaman, pendapatan non-bunga dan pertumbuhan ekonomi adalah indikator profitabilitas yang signifikan (Yüksel, Mukhtarov, Mammadov, \& Özsarı, 2018). Singh \& Bagga pada penelitiannya menyebutkan bahwa adanya pengaruh positif yang signifikan dari struktur modal pada profitabilitas perusahaan (Singh \& Bagga, 2019).

Leverage menampilkan bahwa leverage keuangan mempengaruhi nilai perusahaan dan profitabilitas secara negative signifikan sedangkan hasil korelasi berpasangan menunjukkan tidak terdapat hubungan linier yang signifikan antara leverage dengan nilai dan profitabilitas perusahaan (Ibrahim \& Isiaka, 2020). Olang (2017) dalam penelitiannya menyampaikan financial leverage mempengaruhi profitabilitas perusahaan. Tulisan lain menyatakan financial leverage mempengaruhi pertumbuhan laba perusahaan secara signifikan (Ndubuisi, I, \& JI, 2019).

Kapitalisasi, ukuran perusahaan, perpajakan, dan tingkat pertumbuhan PDB berpengaruh positif terhadap laba Bank (Shair, SunID, Shaorong, Atta, \& Hussain, 2019). Kinerja entitas baik besar maupun kecil dengan ukuran efek perusahaan, sedangkan kinerja entitas berukuran sedang dengan ukuran efek industri. Ditemukan bahwa ukuran perusahaan, besar atau kecilnya tidak berpengaruh signifikan terhadap kinerja keuangan dan profitabilitas perusahaan (Fernandez, Antelo, Lopez, Rey, \& Jardon, 2019). Tulisan lain menyebutkan bahwa ukuran perusahaan yaitu berpengaruh signifikan secara statistik terhadap profitabilitas perusahaan (Olang, 2017).

Karakteristik bank, struktur industri dan variabel makroekonomi penting dalam menjelaskan profitabilitas bank global. Terkait dengan indikator makro ekonomi, pertumbuhan ekonomi yang lebih tinggi dan inflasi memacu profitabilitas bank (Iacobelli, 2018). Posisi inflasi dalam pertumbuhan ekonomi tidak dapat diabaikan, karena ia membalas secara positif atau negatif. Peran inflasi berpengaruh terhadap ekonomi dan profitabilitas perusahaan (Musarat, Alaloul, \& Liew, 2020). Selain itu adanya hubungan antara tingkat inflasi dan pertumbuhan laba pada perusahaan secara signifikan (Ndubuisi, I, \& JI, 2019). Tulisan lain menyebutkan bahwa inflasi memiliki efek negatif pada perkembangan keuangan dan profitabilitas perusahaan di negara-negara dengan inflasi tinggi dan menengah (Ehigiamusoe, Guptan, \& Narayanan, 2019).

Dalam upaya memperdalam tingkat pengungkapan pengaruh leverage dan ukuran perusahaan terhadap profitabilitas, perlu dilakukan penelitian lebih lanjut mengenai pengaruh leverage terhadap profitabilitas dan ukuran perusahaan terhadap profitabilitas. Febria \& Halmawati (2014) menyatakan bahwa Leverage yang menggunakan indikator debt equity ratio (DER) berpengaruh signifikan positif terhadap profitabilitas perusahaan. Namun berbeda dengan penelitian yang telah dilakukan Ibrahim \& Isiaka (2020) yang menampilkan bahwa leverage mempengaruhi nilai perusahaan dan profitabilitas secara negatif signifikan.

Febria \& Halmawati (2014) menyatakan bahwa ukuran perusahaan yang menggunakan indikator total asset tidak berpengaruh signifikan terhadap profitabilitas perusahaan. Berbeda dengan penelitian yang dilakukan Suteja \& Ginting (2014) yang menyebutkan bahwa total assets memiliki pengaruh positif terhadap profitabilitas perusahaan (ROA), hal ini menunjukkan bahwa peningkatan total assets akan meningkatkan profitabilitas perusahaan (ROA).

Berdasarkan uraian di atas, ada beberapa penelitian yang meneliti tentang profitabilitas perusahaan dan variabel yang mempengaruhinya. Pada penelitian ini berinisiasi untuk meneliti lebih lanjut mengenai leverage dan ukuran perusahaan 
terhadap profitabilitas perusahaan dengan menambahkan inflasi sebagai variabel independen. Pada penulisan ini, peneliti melakukan penelitian pada Bank Umum syariah, melihat perkembangan perusahaan sektor perbankan syariah di Indonesia semakin meningkat, maka penting untuk melihat progress dan prospek Bank umum Syariah di Indonesia. Tujuan penulisan ini adalah untuk menganalisis pengaruh leverage, ukuran perusahaan dan inflasi terhadap profitabilitas Bank Umum Syariah di Indonesia tahun 2012-2019.

Tabel 1

Daftar Bank Umum Syariah Terdaftar Otoritas Jasa Keuangan

\begin{tabular}{c|l|c}
\hline No. & \multicolumn{1}{|c}{ Nama Bank } & $\begin{array}{c}\text { Tahun Mulai } \\
\text { Beroperasi }\end{array}$ \\
\hline 1 & Bank Muamalat & 1992 \\
\hline 2 & Bank Syariah Mandiri & 1999 \\
\hline 3 & BRI Syariah & 2008 \\
\hline 4 & BJB Syariah & 2010 \\
\hline 5 & Bank BNI Syariah & 2010 \\
\hline 6 & Bank Victoria Syariah & 2010 \\
\hline 7 & Bank Mega Syariah & 2004 \\
\hline 8 & Bank Syariah Bukopin & 2008 \\
\hline 9 & Bank Panin Dubai Syariah & 2009 \\
\hline 10 & Bank BCA Syariah & 2010 \\
\hline 11 & BTPN Syariah & 2014 \\
\hline 12 & Maybank Syariah/Bank Net Indonesia & $2010 / 2019$ \\
\hline 13 & Syariah & 2016 \\
\hline 14 & Bank Acek Syariah & 2018 \\
\hline
\end{tabular}

Sumber : Otoritas Jasa Keuangan, 2020

\section{TEORI DAN METODE}

\subsection{Tinjauan Pustaka}

Profitabilitas adalah ukuran yang biasa digunakan dalam pengukuran kinerja perusahaan. Untuk melihat tingkat profitabilitas suatu perusahaan dapat digunakan berbagai cara tergantung pada besar kecilnya laba dan aset modal yang dibandingkan antara satu dengan yang lainnya. Return On Asset (ROA), yaitu kemampuan modal yang ditanamkan pada aktiva perusahaan untuk menghasilkan keuntungan bagi investor. (Febria \& Halmawati, 2014).

Ibrahim dan Isiaka (2020) mengungkapkan bahwa leverage berpengaruh terhadap profitabilitas. Hal ini juga ditemukan oleh penelitian Olang (2017) dan Ndubuisi (2019). Leverage yang menggunakan indikator Debt equity ratio (DER) berpengaruh terhadap profitabilitas yang menggunakan indikator Return On Asset (ROA). Leverage merupakan salah satu rasio keuangan yang menunjukkan hubungan antara hutang perusahaan terhadap modal maupun asset perusahaan. Rasio leverage menggambarkan sumber dana operasi yang digunakan oleh perusahaan (Febria \& Halmawati, 2014).

Menurut Shair, SunID, Shaorong, Atta, \& Hussain (2019) ukuran perusahaan berpengaruh positif terhadap laba Bank. Kinerja suatu entitas berukuran kecil 
maupun besar dipengaruhi oleh efek perusahaan, sedangkan kinerja perusahaan berukuran sedang dipengaruhi oleh efek industri. Ukuran perusahaan dapat berpengaruh terhadap laba perusahaaan sehingga mempengaruhi profitabilitas perusahaan.

Ukuran bank pada umumnya digunakan melihat potential economies atau diseconomies of scale. Variabel ini dapat memberikan dampak yang berbeda terhadap profitabilitas bank. Faktor pertama, bisa menyebabkan hubungan positif antara size bank dan profitabilitas bank, jika ada skala ekonomi yang signifikan. Kedua, dapat menyebabkan hubungan negatif jika peningkatan diversifikasi menyebabkan risiko kredit yang lebih rendah, sehingga dapat menghasilkan pendapatan lebih rendah (Suteja \& ginting, 2014).

Inflasi tahunan Indonesia adalah indikator yang digunakan dalam penelitian ini. Iacobelli (2018) menemukan bahwa inflasi memacu profitabilitas bank. Hal ini didukung oleh Alaloul dkk (2020) bahwa peran inflasi berpengaruh terhadap ekonomi dan profitabilitas perusahaan. Selanjutnya, Ndubuisi dkk (2019) mengemukakan bahwa hubungan antara tingkat inflasi dan pertumbuhan laba pada perusahaan adalah signifikan. Umumnya, inflasi dapat mempengaruhi kinerja perusahaan dalam memperoleh laba, sehingga mempengaruhi profitabilitas perusahaan.

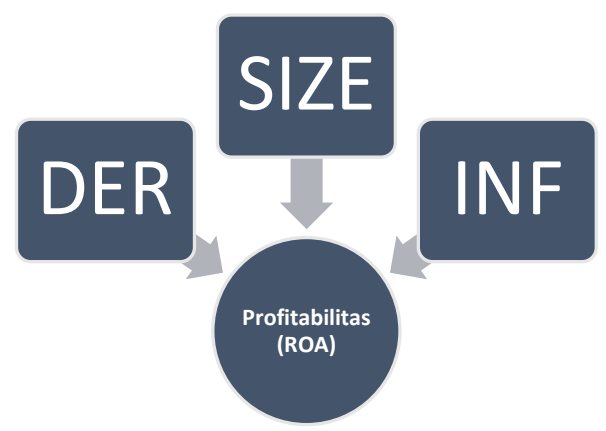

Gambar 1: Model Penelitian

Dari model penelitian diatas, maka dapat ditarik hipotesis sebagai berikut:

H1 : Variabel leverage (DER) berpengaruh signifikan terhadap profitabilitas (ROA)

H2 : Variabel ukuran perusahaan (size) berpengaruh signifikan terhadap profitabilitas (ROA)

H3 : Variabel inflasi (INF) berpengaruh signifikan terhadap profitabilitas (ROA)

H4 : Variabel DER, Size, dan Inflasi secara simultan berpengaruh terhadap profitabilitas (ROA)

\subsection{Metode Penelitian}

Objek penelitian yaitu Perusahaan sektor Perbankan atau Bank Umum Syariah yang resmi terdaftar di (OJK) Otoritas Jasa Keuangan dengan periode 2012 sampai 2019. Dalam tulisan ini mengguakan data penelitian berupa data sekunder yaitu bersumber dari laporan keuangan tahunan yang tersedia di Otoritas Jasa Keuangan dan atau laporan keuangan di masing-masing Bank. Sedangkan dalam pengambilan sampel pada penelitian ini teknik yang digunakan adalah teknik purposive sampling.

Metode analisis data pada penelitian ini menggunakan metode regresi data panel, yaitu penggabungan data cros section dan data time series dengan menggunakan data 10 Bank Umum Syariah dan periode 8 tahun. Regresi data panel menggunakan beberapa metode untuk mengestimasi regresi data panel, diantaranya 
common effect model (CEM), fixed effect model (FEM) dan random effect model (REM). Untuk menentukan pemilihan model estimasi regresi data panel yaitu bisa menggunakan uji chow dan uji hausman.

\section{HASIL DAN PEMBAHASAN}

\subsection{Hasil Analisis Data}

Pada penelitian ini melakukan estimasi berupa regresi data panel untuk mengetahui pengaruh leverage, ukuran perusahaan dan inflasi terhadap profitabilitas pada Perbakan yaitu Bank Umum Syariah tahun 2012 sampai 2019. Berikut adalah hasil estimasi menggunakan software eviews 10 :

1. Uji Pemilihan Model

a) Hasil Uji Chow

Uji Chow dilakukan untuk menguji model yang terbaik diantara model CEM dan FEM.

Tabel 2 Hasil Uji Chow

\begin{tabular}{ccccc}
\hline \hline Effects Test & Statistic & d.f. & Prob. \\
\hline \hline $\begin{array}{l}\text { Cross-section F } \\
\begin{array}{c}\text { Cross-section } \\
\text { square }\end{array}\end{array}$ & Chi- & $\begin{array}{l}4.724921 \\
39.31630\end{array}$ & $(9,67)$ & 0.0001 \\
\hline \hline
\end{tabular}

Sumber: data diolah

Dari hasil uji chow pada tabel di atas, menunjukkan nilai prob pada Crosssection sebesar 0,0000 yang dimana nilainya $<0,05$. Maka dapat diambil kesimpulan bahwa model FEM lebih baik dibandingkan dengan model CEM.

b) Hasil Uji Hausman

Uji Hausman digunakan untuk menguji model yang terbaik diantara model FEM dan model REM.

Tabel 3 Hasil Uji Hausman

\begin{tabular}{cccc}
\hline \hline Test Summary & $\begin{array}{c}\text { Chi-Sq. } \\
\text { Statistic }\end{array}$ & $\begin{array}{c}\text { Chi-Sq. } \\
\text { d.f. }\end{array}$ & Prob. \\
\hline \hline $\begin{array}{l}\text { Cross-section } \\
\text { random }\end{array}$ & 10.147876 & 3 & 0.0174 \\
\hline \hline
\end{tabular}

Sumber : data diolah

Berdasarkan hasil Uji Hausman pada tabel di atas, diperoleh nilai prob sebesar $0.0174<$ Alpha 5\% atau 0,05 maka dapat diambil kesimpulan bahwa model yang terbaik adalah Fixed Effect Model (FEM).

\section{Pengujian Hipotesis}

Berdasarkan hasil uji pemilihan model di atas, maka model estimasi yang terpilih adalah Fixed Effect Model. Berikut hasil regresi Fixed Effect Model: 
Tabel 4

Hasil Regresi Fixed Effect Model

\begin{tabular}{lrrr}
\hline \multicolumn{1}{c}{ Variable } & Coefficient & t-Statistic & Probability \\
\hline C & 15.07136 & 0.959580 & 0.3407 \\
DER & 1.573734 & 3.604555 & 0.0006 \\
SIZE & -6.597967 & -1.185370 & 0.2401 \\
INFLASI & -0.279588 & -0.884053 & 0.3798 \\
R-Squared & & 0.413945 & \\
Adjusted R-Squared & & 0.308980 & \\
F-Statistic & & 3.943643 & \\
Prob (F-Statistic) & & 0.000137 & \\
\hline
\end{tabular}

Sumber : data diolah

Hasil uji t pada tabel 4 diatas menunjukkan bahwa variabel leverage (DER) berpengaruh signifikan terhadap profitabilitas (ROA) dengan nilai sig $<0.05$ yaitu 0.0006 dengan tingkat koefisien yaitu 15.07136. Variabel SIZE dan Inflasi tidak berpengaruh signifikan terhadap Profitabilitas (ROA). Nilai probabilitas variabel SIZE yaitu 0.2401 dengan nilai koefisien -6.597967. Nilai probabilitas variabel Inflasi 0.3798 dengan nilai koefisien -0.279588 .

Jika dilihat dari Koefisien determinasi (R2) yang menunjukkan sejauh mana kemampuan variabel bebas secara bersama-sama dalam menjelaskan variabel terikat. Berdasarkan tabel 4 diatas, diperoleh tingkat koefisien determinasi (R2) adalah 0.413945. dimana menunjukkan variabel independen (DER, SIZE, Inflasi) mampu menejelaskan variabel dependen (Profitabilitas) sebesar 41.39\% sedangkan selebihnya dijelaskan oleh variabel lain selain yang ada pada model penelitian ini.

\subsection{Pembahasan}

a) Pengaruh Leverage terhadap profitabilitas Bank Umum Syariah Nilai koefisien dari variabel DER sebesar 1.573734 dengan nilai prob 0.0006 . hasil ini menampilkan bahwa variabel DER berpengaruh signifikan terhadap variabel profitabilitas dan memiliki hubungan positif, dapat diartikan ketika ada terjadi kenaikan nilai DER sebesar 1 persen maka nilai profitabilitas akan bertambah sebesar 1.57 persen. Temuan ini serupa dengan hasil penelitian yang dilakukan oleh Febria \& Halmawati (2014) yang menyebutkan bahwa leverage dengan indikator DER memiliki pengaruh positif signifikan terhadap profitabilitas.

Hasil penelitian ini serupa dengan penelitian Ibrahim dan Isiaka (2020) bahwa leverage berpengaruh terhadap profitabilitas, namun memiliki perbedaan arah dimana pada penelitian Ibrahim dan Isiaka leverage berpengaruh negatif terhadap profitabilitas. DER menggambarkan sampai mana modal pemilik dapat menutupi utangg kepada pihak luar, rasio ini disebut dengan rasio leverage. Semakin besar leverage maka memungkinkan aset dan sumber dana yang besar bisa digunakan untuk meningkatkan kegiatan usaha sehingga mampu meningkatkan profitabilitas.

Penelitian ini sesuai dengan penelitian Singh \& Bagga (2019) yang menyebutkan bahwa terdapat pengaruh positif yang signifikan dari struktur modal terhadap profitabilitas perusahaan. Pada penelitian ini menggunakan 
Debt Equity Ratio (DER) sebagai indikator untuk mengukur pengaruh terhadap profitabilitas. Jika nilai DER tinggi, maka profitabilitas meningkat.

b) Pengaruh ukuran perusahaan terhadap profitabilitas Bank Umum Syariah Berdasarkan hasil dari uji didapatkan tingkat koefisien variabel Size sebesar 6.597967 dengan tingkat prob 0.2401 . Nilai probabilitas atau signifikansi > 0.05 sehingga variabel size tidak berpengaruh signifikan terhadap profitabilitas. Temuan ini serupa dengan penelitian Febria \& Halmawati (2014) yang menunjukkan bahwa ukuran perusahaan tidak berpengaruh signifikan terhadap profitabilitas.

Menurut Shair, SunID, Shaorong, Atta, \& Hussain (2019) ukuran perusahaan berpengaruh positif terhadap laba Bank. Kinerja entitas besar maupun kecil ditampilkan oleh efek perusahaan, dengan beberapa alasan berbeda, sedangkan kinerja entitas berukuran sedang ditampilkan oleh efek industri. Dilihat dari uraian tersebut, ukuran perusahaan dapat berpengaruh terhadap laba atau profitabilitas, namun terdapat efek lain yang bisa mempengaruhi hal tersebut.

Penelitian ini sesuai dengan penelitian Fernandez, Antelo, Lopez, Rey, \& Jardon (2019) ditemukan bahwa ukuran entitas, besar atau kecilnya tidak berpengaruh signifikan terhadap kinerja keuangan dan profitabilitas perusahaan. Ukuran perusahaan dalam hal ini menggunakan indikator asset terhadap profitabilitas tidak berpengaruh signifikan. Dimana ukuran perusahaan yang besar juga memiliki kapasitas operasional yang harus dipenuhi juga besar.

Hasil penelitian ini berbeda dengan penelitian yang dilakukan oleh Suteja \& Ginting (2014) yang menyatakan bahwa ukuran perusahaan dengan indikator total aset memiliki pengaruh positif dan signifikan terhadap profitabilitas perusahaan.

c) Pengaruh inflasi terhadap profitabilitas Bank Umum Syariah

Berdasarkan hasil dari uji hipotesis didapatkan tingkat koefisien variabel inflasi sebesar -0.279588 dengan tingkat prob 0.3798 . Nilai probabilitas atau signifikansi $>0.05$ sehingga variabel inflasi tidak berpengaruh signifikan terhadap profitabilitas secara parsial.

Musarat dkk (2020) menemukan bahwa posisi inflasi dalam pertumbuhan ekonomi tidak dapat diabaikan, karena ia membalas secara positif atau negatif. Eigiamusoe dkk (2019) menyebutkan bahwa inflasi memiliki efek negatif pada perkembangan keuangan dan profitabilitas perusahaan di negara-negara dengan inflasi tinggi dan menengah. Hal ini bisa dilihat bahwa inflasi dapat berpengaruh terhadap profitabilitas perusahaan pada kondisi-kondisi tertentu.

Kenaikan atau penurunan inflasi di Indonesia yang masih wajar, bisa menjadi tolok ukur bahwa inflasi bisa saja tidak berpengaruh terhadap profitabilitas perusahaan. Tingkat inflasi suatu Negara yang normal menjadikan perusahaan bisa beroperasi secara normal sehingga inflasi tidak berpengaruh terhadap profitabilitas perusahaan.

d) Pengaruh Leverage, Ukuran Perusahaan dan Inflasi terhadap Profitabilitas Dari hasil estimasi pada penelitian ini dengan nilai sign alpa $5 \%(0,05)$. Hasil estimasi menunjukkan tingkat prob F sebesar 0.000137 lebih kecil dari tingkat signifikansi alpha 5\%. Artinya, variabel leverage (DER), ukuran Perusahaan 
(size), dan inflasi secara signifikan bersama-sama mempengaruhi Profitabilitas.

\section{PENUTUP}

Pada penelitian ini didapatkan hasil penelitian dengan kesimpulan bahwa leverage, ukuran perusahaan, dan inflasi berpengaruh signifikan secara simultan terhadap profitabilitas perusahaan pada Bank Umum Syariah. Sedangkan secara parsial, leverage mempengaruhi profitabilitas Bank umum syariah secara positif dan signifikan. ukuran perusahaan dan inflasi tidak berpengaruh signifikan terhadap profitabilitas Bank umum syariah secara parsial.

Variabel Dalam penelitian ini masih terdapat batasan dan kekurangan sehingga belum dapat menggambarkan secara baik sesuai teori. Keterbatasan dalam penelitian ini yaitu pada obyek penelitian, terdapat data-data ekstrim pada bebrapa laporan keuangan Bank Umum Syariah seperti data yang belum diaudit oleh otoritas jasa keuangan. Pada pemilihan sampel juga terbatas karena beberapa Bank Umum Syariah masih baru beroperasi sehingga data yang dibutuhkan dalam periode waktu belum terpenuhi. Selanjutnya variabel yang digunakan baik secara internal perusahaan dan eksternal perusahaan seperti makroekonomi masih terbatas.

Dari beberapa batasan yang ada pada penelitian ini, saran bagi penelitian selanjutnya bisa memilih obyek yang sesuai harapan dan memenuhi sampel yang dibutuhkan. Selanjutnya jika ada peneliti yang melakukan penelitian berkaitan dengan penelitian ini, bisa menambahkan variabel baik internal perusahaan maupun eksternal perusahaan. Peneliti selanjutnya juga bisa menggunakan kebaruan data yang tersedia sehingga penelitian dapat menjadi terbarui. 


\section{DAFTAR PUSTAKA}

Ehigiamusoe, K. U., Guptan, V., \& Narayanan, S. (2019). The effects of income and inflation on financial development: Evidence from heterogeneous panels. Economics ejournal .

Febria, R. L. \& Halmawati. (2014). Pengaruh Leverage dan Ukuran Perusahaan Terhadap Profitabilitas (Studi Empiris Pada Perusahaan Properti dan Real Estate Yang Terdaftar di BEI Tahun 2009-2012). Jurnal WRA, 313-327.

Fernandez, E., Antelo, S. I., Lopez, V. L., Rey, M. R., \& Jardon, C. M. (2019). Firm and industry effect on small, medium-sized and large firm performance. Business Research Quartely , 25-35.

Iacobelli, A. (2018). Determinants of Profitability: Empirical Evidence from the Largest Global Banks. Financial Analyst .

Ibrahim, U. A., \& Isiaka, A. Q. (2020). Effect of Financial Leverage on Firm Value: Evidence From Selected Firms Quoted on the Nigerian Stock Exchange. European Journal of Business and Management , 124-135.

Le, T. D., \& Ngo, T. (2020). The determinants of bank profitability: a cross country analysis. Central Bank Review , 65-73.

Musarat, M. A., Alaloul, W. S., \& Liew, M. (2020). Impact of inflation rate on construction project budget: a review. Ain Shams Engineering Journal.

Ndubuisi, K., I, J., \& JI, O. (2019). Effect of financial leverage on profit growth of quoted non-financial firms in Nigeria. J Fin Mark, 9-14.

Olang, M. (2017). Effect of Financial Leverage on Profitability of Firms Listed in the Nairobi Securities Exchange. International Journal of Science and Research , 290295.

Pervan, M., Pervan, I., \& Ćurak, M. (2019). Determinants of firm profitability in the Croatian manufacturing industry: evidence from dynamic panel analysis. Economic Research-Ekonomska Istraživanja , 968-981.

Puche, M. D., Miguelez, S. M., Soria, J. A., \& Gamez, M. A. (2020). Multilevel assessment of restaurant profitability: evidence with Europan data. Data in Brief , 1-7.

Rumasukun, M. R., Noch, M. Y., \& Pattiasina, V. (2020). Structural Model of Company Stock Return in Basic and Chemical Industries: Impact of Profitability, Market Value, Liquidity and Leverage. International Research Association for Talent Development and Excellence, 3118-3129.

Shair, F., SunID, N., Shaorong, S., Atta, F., \& Hussain, M. (2019). Impacts of risk and competition on the profitability of banks: Empirical evidence from Pakistan. plos one , 1-27.

Sekaran, Uma \& Bougie, Roger. (2017). Metode Penelitian untuk Bisnis (edisi 6). Jakarta: Salemba Empat.

Singh, N. P., \& Bagga, M. ( 2019). The Effect of Capital Structure on Profitability: An Empirical Panel Data Study. Jindal Journal of Business Research , 65-77.

Suteja, J. \& Ginting, G. (2014). Determinan Profitabilitas Bank : Suatu Studi pada Bank yang Terdaftar di BEI. Jurnal Trikonomika, 62-77.

Widarjono, Agus. (2018). Ekonometrika pengantar dan aplikasinya. Yogyakarta: UPP STIM YKPN.

Yüksel, S., Mukhtarov, S., Mammadov, E., \& Özsarı, M. (2018). Determinants of Profitability in the Banking Sector: An Analysis of Post-Soviet Countries. economies , 1-15.

Otoritas Jasa Keuangan. Laporan Keuangan Perbankan 2012-2019. OJK. 
Halaman ini sengaja dikosongkan 